\title{
Pallet Fixing Lock, Determination of Shear Resistance and Spring Stiffness
}

\author{
Leopold Hrabovský' ${ }^{*}$, Vieroslav Molnár ${ }^{2}$, Gustav Kotajný3, Jozef Kul'ka ${ }^{4}$
}

1 VSB Technical University of Ostrava, Faculty of Mechanical Engineering, Institute of Transport, 17. listopadu 2172/15, 70800 Ostrava - Poruba, Czech Republic

2 Technical University of Košice, Faculty of Manufacturing Technologies with a seat in Prešov, Bayerova 1, 08001 Prešov, Slovak Republic

3 KOMA - Industry s.r.o., Ruská 41, 70602 Ostrava - Vítkovice, Czech Republic

4 Technical University of Košice, Faculty of Mechanical Engineering, Letná 9 Street, 04200 Košice, Slovak Republic

* Corresponding author's e-mail: leopold.hrabovsky@vsb.cz

\begin{abstract}
The paper contains the designs of modifications of testing devices, which were constructed for the purpose of checking the functional properties of the mechanical pallet fixing lock built by the KOMA - Industry s.r.o. company, which is used for securing pallets with cars in parking houses. The individual testing devices consist of one or two positioning devices, the moveable parts of which are placed perpendicular to each other in the frame of the testing device. A mechanical pallet fixing lock is attached to the moving part of the perpendicular positioning device, and it consists of the following three parts: the body, the pulley holder and a compression coil spring. A plate is attached to the moveable part of the horizontal positioning device and is adapted to receive a pressure force sensor or to engage a mechanical fixation lock or the break of an electromagnetic locking device. The paper contains the description and method of experimentally determined resistance, which is created by the shear friction on contact surface, when inserting or withdrawing the pulley holder tube from the plain bushing of the fixation lock body. Additionally, the paper provides the values of the measured vertical forces, which are generated by the deformed compression spring with a wire of circular cross-section during inserting/withdrawing of the pulley holder tube into/from the fixation lock body. The values obtained from the performed experimental measuring of vertical forces and frictional resistance during the inserting of the pulley holder tube into the plain bushing of the fixation lock body will be used for subsequent checking of the functional properties of pallet fixation locks and will allow determining the optimal position for attaching the pallet fixation locks to stack cell steel beams in the parking house, on which chain conveyers push pallets with cars are parked.
\end{abstract}

Keywords: fixation lock of pallets, testing equipment, shear resistance, spring stiffness.

\section{INTRODUCTION}

In [1] two design variants of mechanical parking brakes were presented. These are used for stopping and securing against the spontaneous movement of vehicles on pallets in rack cells in the automatic parking house BRNO Kopečná [2], by KOMA - Industry s.r.o.:

- In the year 2011 - "Parking house Ostrava FEI" [9] with 1 check-in area, 4 parking floors and 37 parking places, in the year 2011;
- in the year 2013 - "Parking house Slaný" with 2 check-in areas, 7 parking floors (1 underground, 6 above ground) and 149 parking places (as of 1 October 2019 this automated parking house, hereinafter referred to as APH) was terminated.

The pallet fixation locks are used in both mentioned APHs (Fig. 1 and Fig. 4) of a design different from that indicated in $[1,2,3]$, the principle of their operation is identical to the locking 


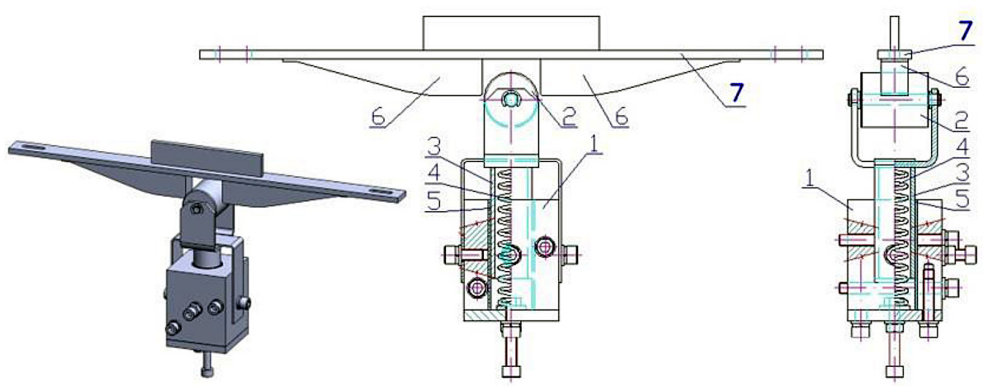

Fig. 1. The fixation pallet lock was put into operation

brakes [1]. In order to verify the functional properties of the pallet fixation lock (Fig. 1) a 2D structural design and a 3D model (Fig. 2) of the testing equipment were made. The device was subsequently constructed for future experimental tests and the measurement of generated forces (Fig. 6 and Fig. 8).

For the optimum operation of the fixation lock, ensure that the horizontal axis of the pulley $\underline{2}$ (Fig. 1) was placed against the top surface of one of the support beams $\underline{6}$ (height $h_{N}$ ) break profile assembly $\underline{7}$ at a distance of $h_{N K}=h_{T O}-h_{N}$ (Fig. 3) smaller than the roller radius $R$ and at a distance greater than zero between distances $h_{K}-h_{N}$.

According to Figure 3 and relationship (1) the distance can be used to determine $L_{x}$ (not dimensioned in Fig. 3), which is able to move the fixation lock in the horizontal plane without deforming the free length $L_{0}$ springs $\underline{4}$ (i.e. inserting the tube $\underline{3}$ pulley bracket assembly $\underline{\mathrm{A}}$ into the body $\underline{1}$ of the fixation lock).

$$
\mathrm{L}_{\mathrm{x}}=2 . \mathrm{L}_{\mathrm{xr}}+\mathrm{x}_{\mathrm{N}}[\mathrm{m}]
$$

assuming that:

$$
\begin{aligned}
& \mathrm{L}_{\mathrm{xr}}=\mathrm{r}-\mathrm{x}_{\mathrm{r}}[\mathrm{m}] \\
& \mathrm{x}_{\mathrm{r}}=\mathrm{r} \cdot \cos \alpha[\mathrm{m}]
\end{aligned}
$$

$$
\text { üụ̈̆ }=\ddot{u} \ddot{u} \quad \text { r }
$$

In a practical application where a fixation lock is used (e. g. APH Ostrava - FEI) [9] or APH Slaný, see Fig. 4) the shortest distance $L_{x}$ possible should be chosen to allow the chain conveyor to securely attach the pallet to the vehicle. The minimum distance $L_{x \min }$ can be determined using Figure 3, according to relationship (5).

$$
\mathrm{L}_{\mathrm{x} \text { min }}=2 . \mathrm{L}_{\mathrm{xr}}+\mathrm{x}_{\mathrm{Nmin}}[\mathrm{m}]
$$

assuming that:

$$
\begin{aligned}
\mathrm{x}_{\mathrm{N} \min } & =2 \cdot \mathrm{R}-2 \cdot \mathrm{L}_{\mathrm{xR}}[\mathrm{m}] \\
\mathrm{L}_{\mathrm{xR}} & =2 \cdot \mathrm{R}-\mathrm{x}_{\mathrm{R}}[\mathrm{m}] \\
\mathrm{x}_{\mathrm{R}} & =\mathrm{R} \cdot \cos \alpha[\mathrm{m}]
\end{aligned}
$$

\section{Resistance force when inserting the pulley holder tube into the fixation lock body}

The purpose of the fixation lock is to fix the pallet with or without the vehicle in the desired position in the appropriate cell of the APH rack. The pallet will be locked upon guiding the pulley $\underline{2}$ fixation lock (Fig. 1 and Fig. 4) into the space

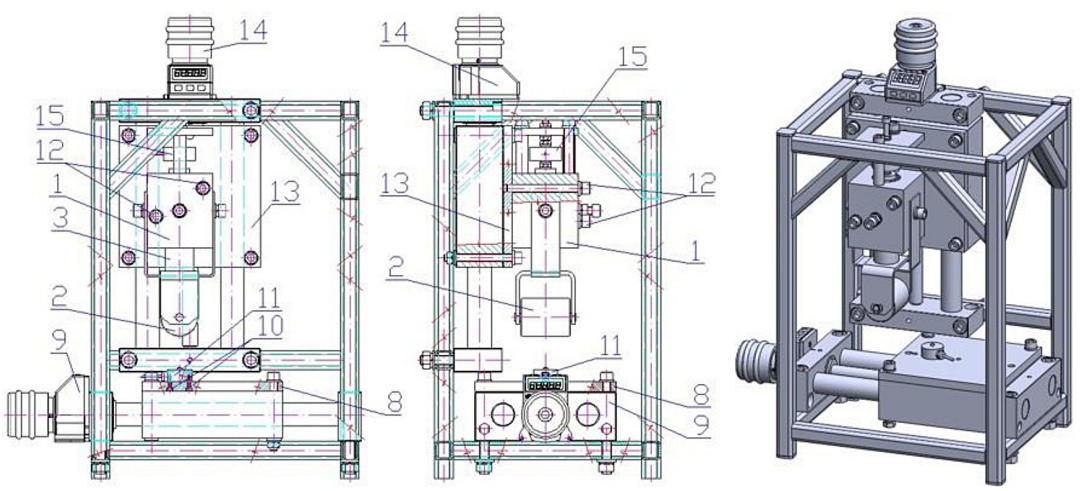

Fig. 2. 2D Design and 3D model of test device to determine friction resistance when inserting pulley holder assembly into fixation lock body 

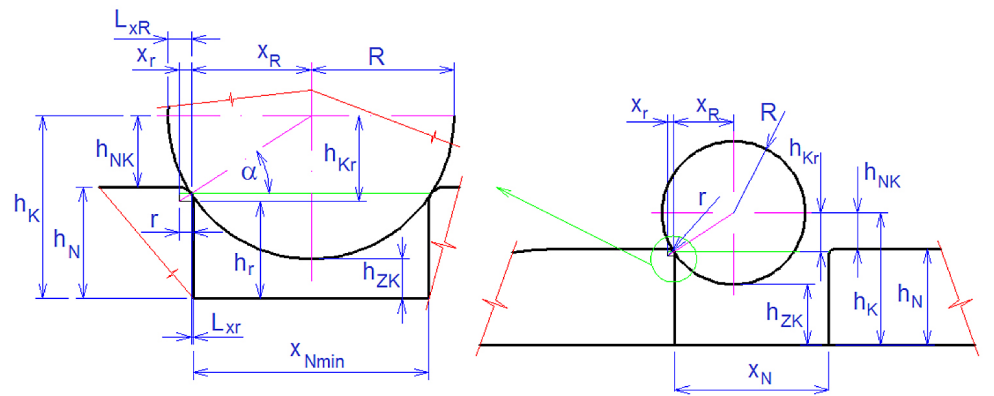

Fig. 3. The pallet fixing lock pulley located in the gap between the face surfaces of the brake profile

between the two faces of the brake profile 6 which are components of the "brake profile assembly $\underline{\underline{ } \text { ". }}$

The amount of force $F$ that must be exerted to push the pulley 2 fixation lock from the space between the two faces of the brake profile $\underline{6}$ of the brake profile assembly $\underline{7}$ is directly proportional to the compressive force $F_{p}$ of deformed springs 4 [5]. The forces in the horizontal plane $F_{x}$ and in the vertical plane $F_{v}$ required to push the pulley $\underline{2}$ from brake profile gap $\underline{7}$ can be determined by calculation according to $[1,3]$. The calculation methodology [3] and experimental measurements [4] show that the spring compression force is influenced by the friction resistance $T$, which is generated by the shear friction in the contact surface of the tube $\underline{3}$ and the plain bushing $\underline{5}$ (Fig. 2) when inserting/withdrawing the "roller holder $\underline{\underline{A}}$ " into/from body 1 of the fixation lock.

For the preferred bearings with clearance in the single hole system $\mathrm{H} 7$ (for inner nominal diameter $30 \mathrm{~mm}$ of the plain bushing $\underline{5}$ ) is (for external nominal diameter of $30 \mathrm{~mm}$ tube $\underline{3}$ ) the basic shaft deviation " $\mathrm{g}$ ", and the degree of accuracy 6 are selected. For the performed bearing $\mathrm{H} 7 / \mathrm{g} 6$ the upper deviation of hole $\mathrm{E}_{\mathrm{s}}=+21 \cdot 10^{-6}$ $\mathrm{m}$, shaft top deflection $\mathrm{e}_{\mathrm{s}}=-7 \cdot 10^{-6} \mathrm{~m}$ and lower shaft deflection $e_{i}=-20 \cdot 10^{-6} \mathrm{~m}$. The tube contact surfaces (outside diameter) $\underline{3}$ and (inner diameter) plain bushing $\underline{5}$ of the pallet fixation lock are greased to reduce the shear friction.

The experimental measurement of the frictional resistance during tube insertion/withdrawal $\underline{3}$ into/from the body $\underline{1}$ fixation lock was performed at the measuring station (Fig. 2) in order to obtain the real values of the acting vertical force components $F_{y s}$ (induced deformations of the compression spring $\underline{4}$ and frictional force) generated by the fixation lock depending on the insertion/ withdrawal (length of the resilient spring 4 ) of the tubes $\underline{3}$ of the pulley bracket assembly $\underline{\text { A }}$ (Fig. 5) into/from the body 1 of the fixation lock. The tube $\underline{3}$ of the pulley bracket assembly $\underline{A}$ was inserted into the body 1 of the fixation lock.

The amount of friction resistance $T$ was determined by three experimental procedures. The first procedure of the experimental determination of the friction resistance was carried out as follows: the body 1 of fixation pallet lock was mounted onto plate $\underline{13}$ of the vertical positioning device $\underline{14}$ [6] by screws $\underline{12}$ (Fig. 10a). The tube $\underline{3}$ of the pulley bracket assembly $\underline{\mathrm{A}}$ was inserted into body $\underline{1}$ of the fixation lock, while the upper lid was not fastened to the pallet fixation lock body $\underline{1}$. The compression spring $\underline{4}$ was inserted into the tube $\underline{3}$ of the pulley bracket assembly $\underline{A}$ through an opening in the upper surface of body 1 .

Due to the own weight of spring 4 and the weight of the pulley holder assembly $\underline{\mathrm{A}}$, the pulley $\underline{2}$ of the fixation lock exerted the pressure force $F_{k l}$ onto pin 27, which was screwed onto the threaded part of the digital load cell 28 [8]. The body of the digital load cell 28 was attached to the load cell holder weldment $\underline{30}$ by screw connections $\underline{31}$ with screws $\underline{29}$ to the welded steel frame
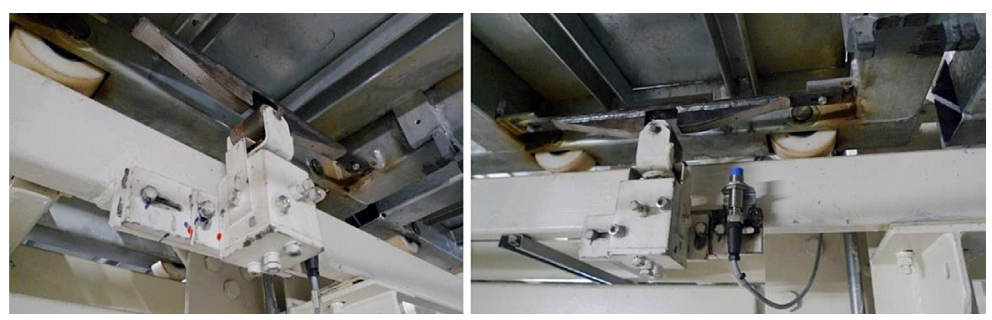

Fig. 4. Fixing pallet lock with an installation stop, in APH Slaný [2] 

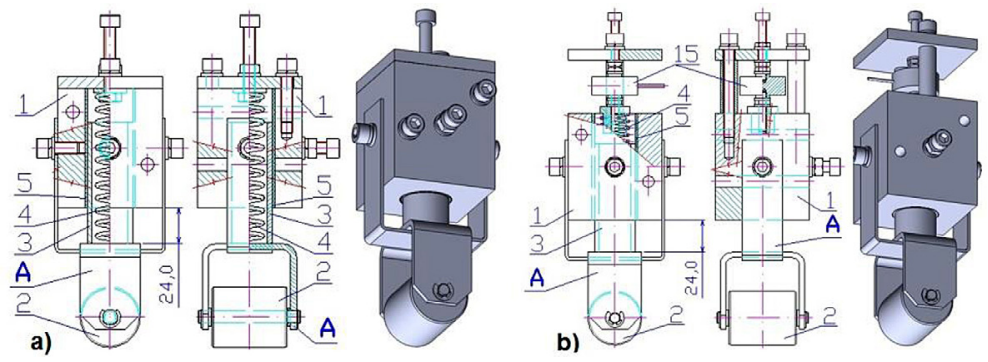

Fig. 5. Pallet fixing lock a) original design, b) modified design
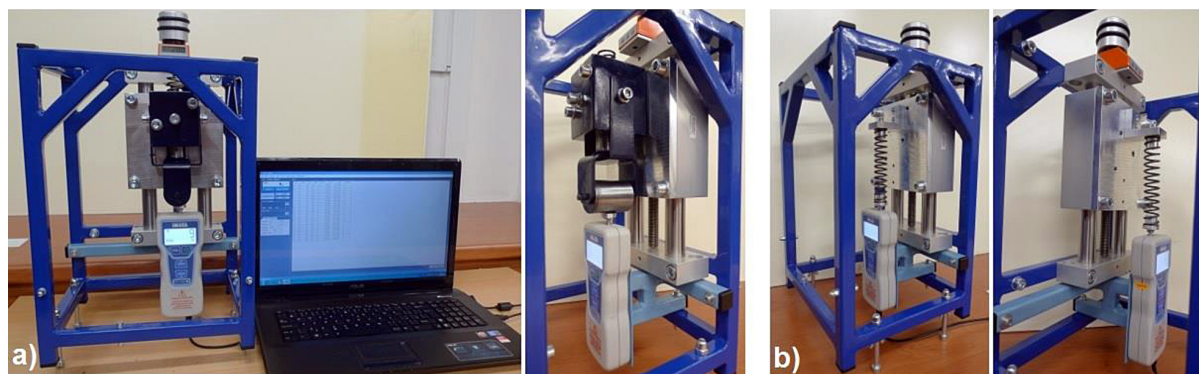

Fig. 6. Measuring station for determining a) 1st friction resistance variant, b) spring stiffness

of the pallet fixation lock tester. By changing the position of the moveable part of the vertical positioning device $\underline{14}$ tube $\underline{3}$ of the pulley bracket assembly $\underline{A}$ was gradually inserted into body $\underline{1}$ of the fixation pallet lock (Fig. 6a).

The pressure force $F_{k l}$ exerted by self weight $G_{K}$ of the pulley holder assembly $\underline{\mathrm{A}}$, by the weight of $G_{P}$ springs $\underline{4}$ and friction resistance $T_{1 i}$ when inserting tube $\underline{3}$ into body $\underline{1}$ of the fixation lock by value $y_{i}$; was recorded by a digital load cell $\underline{28}$ into the IMADA Force Logger data management software ver.1.01 [12] on a PC. The frictional resistances $T_{1 i}$ were determined from the measured values of forces $F_{k l i}$ by relationship (9), the mean value of the friction resistance $T_{l s}$ was then calculated (Table 1).

$\mathrm{T}_{1(2) \mathrm{i}}=\mathrm{F}_{\mathrm{k} 1(2) \mathrm{i}}-\mathrm{G}_{\mathrm{K}}-\mathrm{G}_{\mathrm{P}}=\mathrm{F}_{\mathrm{k} 1(2) \mathrm{i}}-\mathrm{G}_{\mathrm{KP}}[\mathrm{N}]$

During the second procedure, a pressure force sensor 11 [11] was fastened with screws $\underline{10}$ to plate $\underline{8}$ of the horizontal positioning device $\underline{9}$ [6], see Fig. 2. Pulley roller $\underline{2}$ of fixation lock (original design, see Fig. 5a) the body 1 of which was fastened with screws 12 to plate $\underline{13}$ of the vertical positioning device $\underline{14}$ was in contact with the measuring surface of sensor $\underline{11}$. In changing the position of the moveable part of the vertical positioning device $\underline{14}[6]$ the tube $\underline{3}$ of the pulley bracket assembly A was inserted into body 1 of the fixation lock (in the state when the upper lid was not fastened to the body 1 of the pallet fixing lock; when inserting tube $\underline{3}$ into body 1 there was no deformation of the compression coil spring 4 ) (Fig. 8a). When inserting tube $\underline{3}$ of pulley bracket assembly $\underline{A}$ into body 1 of the fixation lock, it generates frictional force $T$ due to the shear friction in the contact surfaces (between the outer surface of the tube $\underline{3}$ and the inner surface of the plain bush $\underline{5}$ ). The pressure force $F_{k 2}$ generated by the self-weight $G_{K}$ of the pulley holder assembly $\underline{\mathrm{A}}$, the weight of $G_{P}$ springs $\underline{4}$ and by friction resistance $T_{2 i}$ during insertion of tube $\underline{3}$ into body 1 of the fixation lock by value $y_{i}$; recorded by sensor 11 and the DEWESoft X2 SP5 measuring software (Table 2). The frictional resistances $T_{2 i}$ and the mean friction resistance value $T_{2 s}$ were determined from the recorded forces $F_{k 2 i}$ by relationship (9).

The determination of the frictional resistance value $T$ by the third method was carried out as follows: a force sensor 11 was fastened with screws

Table 1. The mean value of the friction resistance

\begin{tabular}{|c|c|c|c|c|c|c|c|c|c|}
\hline $\mathrm{y}_{\mathrm{i}} \cdot 10^{-3}[\mathrm{~m}]$ & 2 & 4 & 6 & 8 & 10 & 12 & 14 & 16 & \\
\hline $\mathrm{F}_{\mathrm{k} 1 \mathrm{i}}[\mathrm{N}]$ & 9 & 10 & 10 & 11 & 10 & 11 & 11 & 11 & \\
\hline $\mathrm{T}_{1 \mathrm{i}}[\mathrm{N}]$ & 0.1 & 1.1 & 1.1 & 2.1 & 1.1 & 2.1 & 2.1 & 2.1 & $\mathrm{~T}_{1 \mathrm{~s}}=\sum \mathrm{T}_{1 \mathrm{i}} / \mathrm{n}=1.4 \mathrm{~N}$ \\
\hline
\end{tabular}


Table 2. Pressure force values

\begin{tabular}{|c|c|c|c|c|c|c|c|c|c|}
\hline $\mathrm{y}_{\mathrm{i}^{\cdot}} 10^{-3}[\mathrm{~m}]$ & 2 & 4 & 6 & 8 & 10 & 12 & 14 & 16 & \\
\hline $\mathrm{F}_{\mathrm{k} 2 \mathrm{i}}[\mathrm{N}]$ & 9.8 & 9.6 & 10.1 & 9.9 & 10.6 & 11.1 & 11.3 & 11.2 & \\
\hline $\mathrm{T}_{2 \mathrm{i}}[\mathrm{N}]$ & 0.9 & 0.7 & 1.2 & 1.0 & 1.7 & 2.2 & 2.4 & 2.3 & $\mathrm{~T}_{2 \mathrm{~s}}=\Sigma \mathrm{T}_{2 \mathrm{i}} / \mathrm{n}=1.6 \mathrm{~N}$ \\
\hline
\end{tabular}

10 to plate $\underline{8}$ of the horizontal positioning device $\underline{9}$ [6], see Fig. 2. Pulley $\underline{2}$ of fixation lock (modified design, see Fig. 5b) the body 1 of which was fastened by two screws $\underline{12}$ to plate $\underline{13}$ of the vertical positioning device $\underline{14}$ was brought into contact with the measuring surface of the sensor $\underline{11}$. In changing the position of the moveable part of the vertical positioning device $\underline{14}$ [6], the tube $\underline{3}$ of the pulley bracket assembly $\underline{A}$ was inserted into the body 1 of the fixation lock, while reducing the free length $L_{0}$ of the compression coil spring 4 (Fig. 7b). The sensor 15 was installed at the top of the structurally modified pallet fixation lock (Fig. 5b), and recorded the amount of pushing force $F_{s i}$ of the compression spring 4 generated when inserting the tube $\underline{3}$ of the pulley bracket assembly $\underline{\mathrm{A}}$ into the body $\underline{1}$ of the fixation lock by value $y_{i}$.

The pressure force $F_{k 3}$; generated by the self-weight of the pulley holder assembly $G_{K}$, spring load $G_{p}$ and the pressing force $F_{p i}$ of deformed springs $\underline{4}[5]\left(d=2.5 \mathrm{~mm}, D_{e}=22.5 \mathrm{~mm}\right.$, $L_{0}=120 \mathrm{~mm}, \mathrm{n}=12.5$, see Fig. 8 , stiffness $k_{p}$ $=3.98 \mathrm{~N} / \mathrm{mm}$ ), see Fig. 2 and Fig. 5, acting on the sensor 11; was recorded with the DEWESoft X2 SP5 measuring program, see Fig. 11 and Table 3, and compared with the recorded compressive force $F_{s i}$ acting on the sensor $\underline{15}$. The force difference $\left(F_{k 3 i}-G_{T O}-G_{p}-F_{s i}\right)$ is defined as the resistance $T_{3 i}$ against insertion of the tube $\underline{3}$ pulley of the bracket assembly $\underline{\mathrm{A}}$ into the body $\underline{1}$ of the pallet fixation lock.

The dimensions presented in Figure 3 are selected for the actual pallet fixation locks in parking buildings and are as follows: $h_{N}=27 \mathrm{~mm} ; R=$ $20 \mathrm{~mm} ; h_{K}=32 \mathrm{~mm}, h_{Z K}=h_{K}-R=12 \mathrm{~mm}$. With these dimensions, the moment the pulley $\underline{2}$ rolls over the top of the brake profile $\underline{6}$, the tube $\underline{3}$ is inserted into the body $\underline{1}$ by $h_{N}-h_{Z K}=15 \mathrm{~mm}$. It is possible to withdraw the tube $\underline{3}$ from the body $\underline{1}$ by max. value $y_{T T}=24 \mathrm{~mm}$ (Fig. 5).

Table 3 presents the values of compressive forces $F_{k 3}$ and $F_{s i}$ recorded by sensors $\underline{11}$ and $\underline{15}$ generated by inserting the tube $\underline{3}$ into the body $\underline{1}$ of the fixation lock. Given the known weight of the pulley holder assembly $\underline{\mathrm{A}} G_{K}=8.53 \mathrm{~N}$, spring load $\mathrm{G}_{\mathrm{p}}=0.35 \mathrm{~N}\left(G_{T O}+G_{P}=G_{K P}=8.9 \mathrm{~N}\right)$ and insertion sizes $y_{i}=<0 ; 16>\mathrm{mm}$ tubes $\underline{3}$ into the body 1 of fixation lock on the vertical plane are calculated according to the relationship (10), resistance values $T_{3 i}$ (Table 3 ).

$$
\mathrm{T}_{3 \mathrm{i}}=\mathrm{F}_{\mathrm{k} 3 \mathrm{i}}-\mathrm{G}_{\mathrm{K}}-\mathrm{G}_{\mathrm{P}}-\mathrm{F}_{\mathrm{si}}=\mathrm{F}_{\mathrm{k} 3 \mathrm{i}}-\mathrm{G}_{\mathrm{KP}}-\mathrm{F}_{\mathrm{si}}[\mathrm{N}](10)
$$
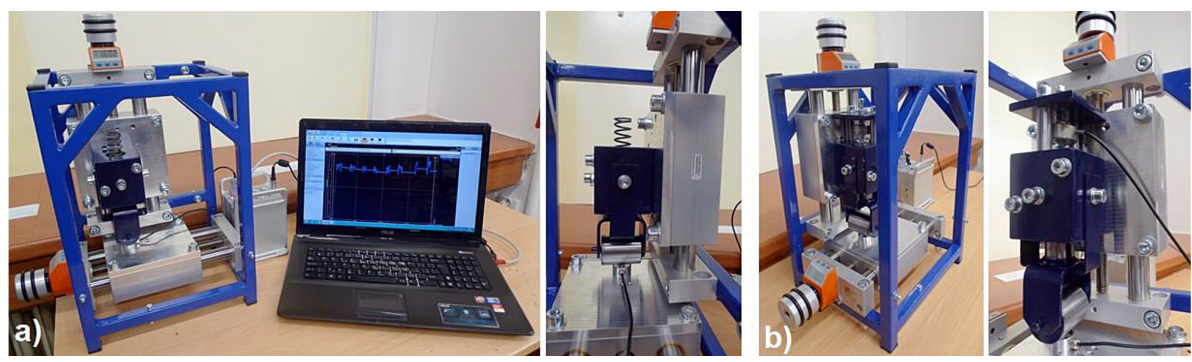

Fig. 7. Experimental measuring station for finding the friction resistance values of a) 2 nd variant, b) 3 rd variant

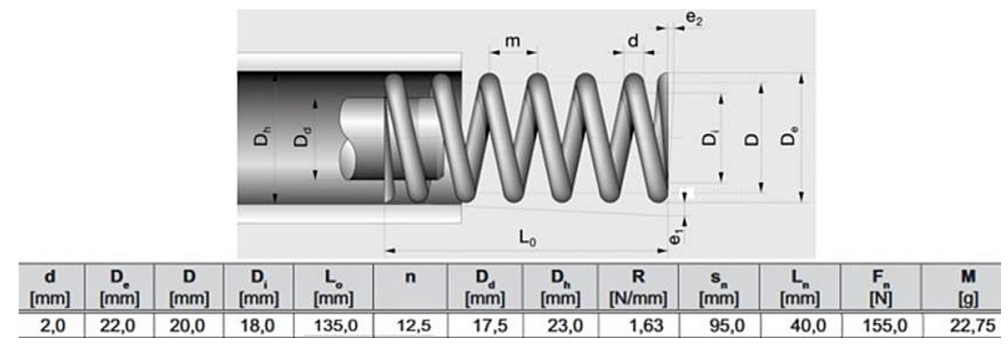

Fig. 8. Compression cylindrical spring wire of circular cross-section with constant diameter [5] 
Table 3. Resistance values

\begin{tabular}{|c|c|c|c|c|c|c|c|c|c|c|}
\hline $\mathrm{y}_{\mathrm{i} \cdot} \cdot 10^{-3}[\mathrm{~m}]$ & 0 & 2 & 4 & 6 & 8 & 10 & 12 & 14 & 16 & \\
\hline $\mathrm{F}_{\mathrm{pi}}[\mathrm{N}]$ & 90.55 & 98.51 & 106.47 & 114.43 & 122.39 & 130.35 & 138.31 & 146.27 & 154.23 & \\
\hline $\mathrm{F}_{\mathrm{si}}[\mathrm{N}]$ & 90.7 & 99.7 & 105.9 & 113.7 & 121.4 & 130.3 & 137.8 & 145.7 & 149.8 & \\
\hline $\mathrm{F}_{\mathrm{k} 3 \mathrm{i}}[\mathrm{N}]$ & 0.0 & 109.4 & 116.7 & 123.5 & 131.6 & 141.1 & 148.7 & 155.9 & 160.7 & \\
\hline $\mathrm{T}_{3 \mathrm{i}}[\mathrm{N}]$ & 0.0 & 0.8 & 1.9 & 0.9 & 1.3 & 1.9 & 2.0 & 1.3 & 2.0 & $\mathrm{~T}_{3 \mathrm{~s}}=1.5 \mathrm{~N}$ \\
\hline
\end{tabular}

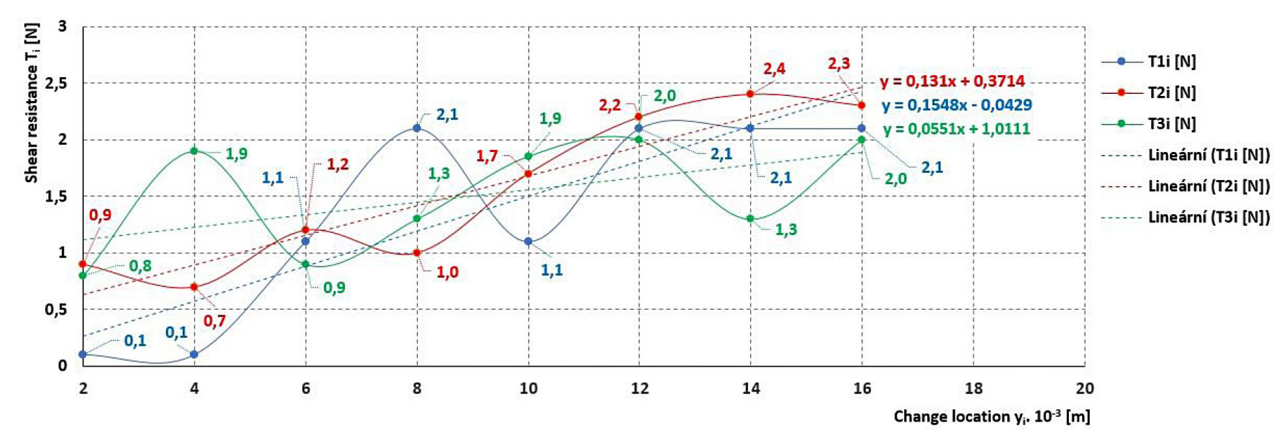

Fig. 9. Frictional forces $T_{1 i}, T_{2 i}$ and $T_{3 i}$ generated by shear friction in the contact surfaces of tube $\underline{3}$ of the pulley bracket assembly $\underline{\mathrm{A}}$ and into the body $\underline{1}$ pallet fixation lock

The second line of Table 3 contains the theoretically calculated values according to the equation (11) values of compressive force $F_{p i}$ produced by the spring $\underline{4}$ when pressed $y_{i}$ and initial transformation of $\mathrm{y}_{1}=22.75 \mathrm{~mm}$.

$$
\mathrm{F}_{\mathrm{pi}}=\mathrm{k}_{\mathrm{p}} \cdot\left(\mathrm{y}_{1}+\mathrm{y}_{\mathrm{i}}\right)[\mathrm{N}]
$$

The values of the obtained frictional forces $T_{1 i}, T_{2 i}$ and $T_{3 i}$ generated by the shear friction in the contact surfaces when inserting the tube $\underline{3}$ of the pulley bracket assembly $\underline{\mathrm{A}}$ into the body $\underline{1}$ of the palette fixation lock, of three experimental procedures (Fig. 9) were compared, followed by a calculation that gave the friction resistance value $T$, which will be taken into account in the experimental measurements, enabling to determine the values of the acting vertical components of forces $F_{v s}$ when pushing the pulley roller $\underline{2}$ of the pulley bracket assembly $\underline{A}$ of the fixation lock (Fig. 1 and Fig. 4) from the space between the two faces of the break profile $\underline{6}$ which are parts of the "brake profile assembly $\underline{\text { " }}$

\section{EXPERIMENTAL VERIFICATION OF COMPRESSION SPRING STIFFNESS}

Hrabovsky and Dluhos [10] describes the experimental measurement of cylindrical coil spring compression depending on the amount of the exerted compressive force and gives the mean value of spring stiffness [8] used in the pallet fixation lock.

The stiffness $k_{p}$ of compression coil springs 4 [5] was experimentally measured as follows: a bracket $\underline{24}$ was mounted onto the plate 13 of the vertical positioning device $\underline{14}$ [6] with screws $\underline{23}$ (Fig. 10b). One end of the spring 4 was threaded onto the pin $\underline{25}$, which was attached to the console $\underline{24}$ with screw $\underline{26}$, the other end of the spring $\underline{4}$
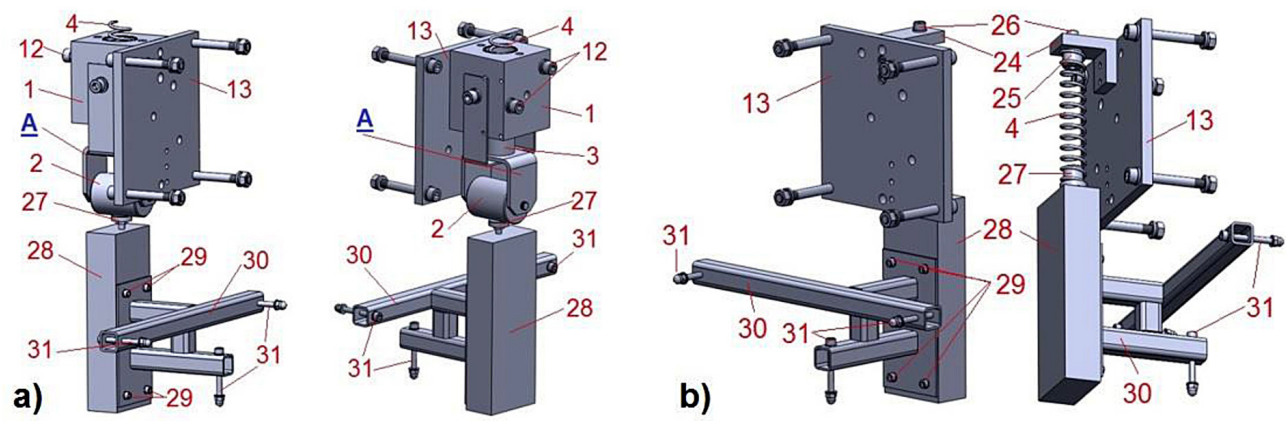

Fig. 10. Device for the determining of a) frictional resistance, b) stiffness of the compression coil spring 


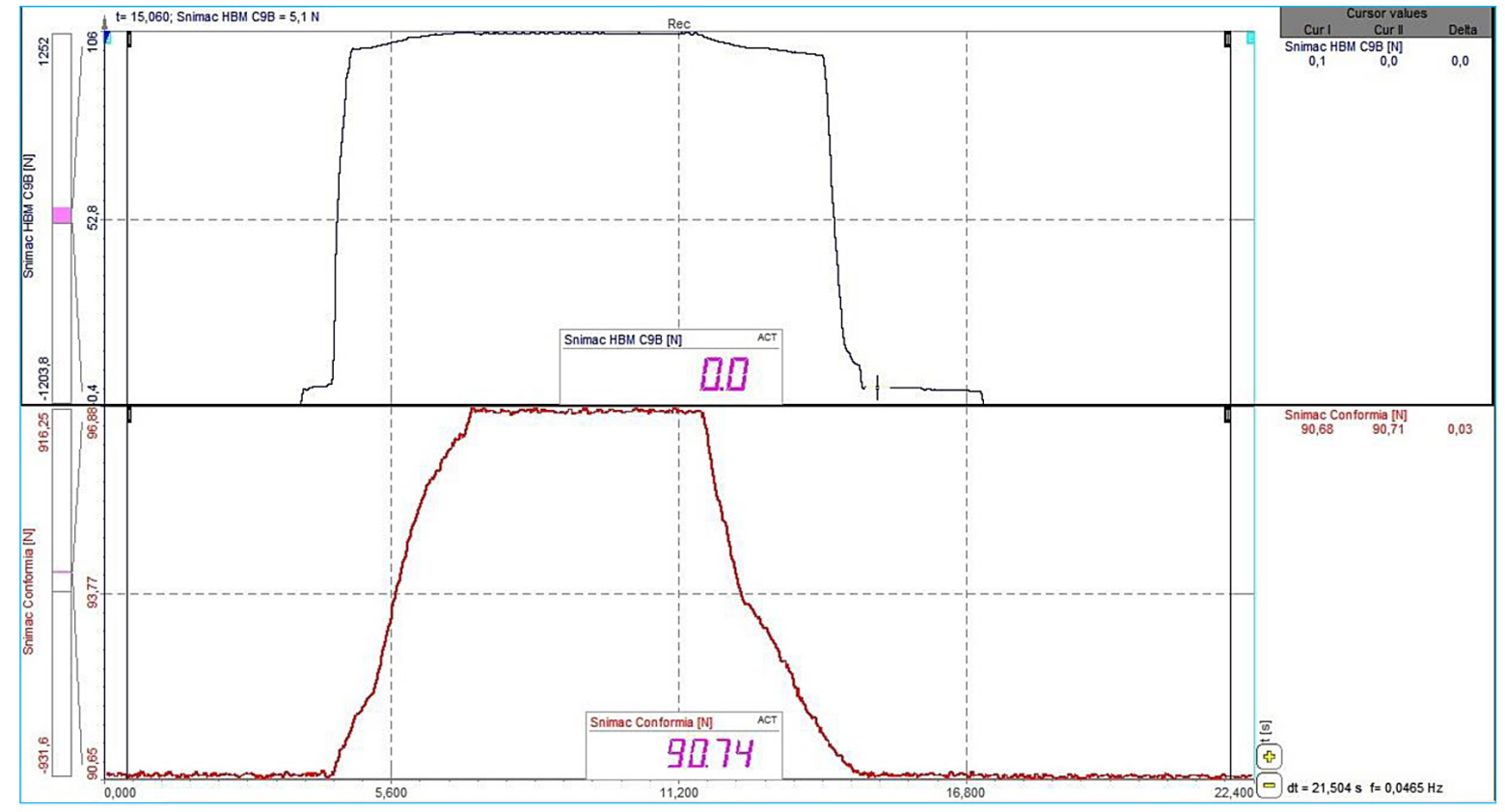

Fig. 11. Recording of forces $F_{s i}$ and $F_{k 3 i}$ in DEWESoft X2 SP5

Table 4. Compressive force values

\begin{tabular}{|c|c|c|c|c|c|c|c|c|c|c|c|c|}
\hline $\mathrm{y}_{\mathrm{i}^{\cdot}} \cdot 10^{-3}[\mathrm{~m}]$ & 2 & 4 & 6 & 8 & 10 & 12 & 14 & 16 & 18 & 20 & 22 & \\
\hline $\mathrm{F}_{\mathrm{pi}}[\mathrm{N}]$ & 7 & 13 & 22 & 29 & 37 & 44 & 52 & 60 & 68 & 76 & 83 & \\
\hline $\mathrm{k}_{\mathrm{pi}}[\mathrm{N} / \mathrm{mm}]$ & 3.5 & 3.5 & 3.7 & 3.6 & 3.7 & 3.7 & 3.7 & 3.8 & 3.8 & 3.8 & 3.8 & $\Sigma \mathrm{k}_{\mathrm{pi}} / \mathrm{n}=3.7$ \\
\hline
\end{tabular}

was threaded onto the pin $\underline{27}$. Pin $\underline{27}$ was screwed onto the threaded part of the digital load cell 28 . The body of the digital load cell 28 was attached to the load cell holder weldment $\underline{30}$ by screw connections $\underline{31}$ with screws $\underline{29}$ to the welded steel frame of the pallet fixation lock tester.

In changing the position of the moveable part 14.1 of the vertical positioning device $\underline{14}$, there was a gradual compression of the compression spring $\underline{4}$ (Fig. 6b). The compressive force $F_{p i}$ (Table 4) corresponding to the given change $y_{i}$ original length $L_{0}$ springs 4 was recorded by a digital load cell $\underline{28}$ in the IMADA Force Logger data management software ver.1.01 [12] on a PC.

\section{CONCLUSION}

The paper presents the shear friction values obtained by three chosen procedures, conducted on two built modified versions of the testing device. These shear friction values were generated by resistance on the contact surface during inserting/withdrawing the tube into/from the body of the palette fixation lock. The tests determined the stiffness of the compression cylindrical spring coil, i.e. the rate of change in the length of the spring in relation to the external forces during elastic deformation.

The experimentally obtained frictional resistance values when inserting the pulley holder assembly tube into the fixation lock body and measuring the spring compression value obtained when compressing the spring will be used for subsequent experimental tests to obtain the horizontal force values during the guiding of the pulley into the gap between the front faces of the brake profile; when the pulley is rolling along the brake profile. Carrying out experimental measurements, the aim of which is to obtain the values of the forces generated when pushing the pulley out of the gap between the two faces of the brake profile, is also envisaged.

\section{Acknowledgements}

This work has been supported by The Ministry of Education, Youth and Sports of the Czech Republic from the Specific Research Project SP2020/90. 


\section{REFERENCES}

1. Hrabovsky L. and Mlcak, T. Vertical forces acting on the lock-off element of the pallet brake system. Advances Science and Technology Research Journal, 14(1), 2020.

2. http://komaindustry.cz/home/divize-automatickych-parkovacich-systemu/22-parkovaci-dumbrno-kopecna

3. Hrabovsky L., Mlcak T. and Kotajny G. Forces Generated in the Parking Brake of the Pallet Locking System. Advances Science and Technology Research Journal, 13(4), 2019, 181-187.

4. Hrabovsky L. and Zacek, V. Forces in the lock-off device during the rolling of the brake pulley roller over the brake ramp in the built automatic parking house. IOP Conference Series: Materials Science and Engineering, 2020. In press.

5. https://www.hennlich.cz//fileadmin/_migrated/cz Tla\%C4\%8Dn\%C3\%A9_pru\%C5\%BEiny_-_tabulky_patent_1_6-2_8.pdf

6. https://www.mnsystems.cz/manualni-polohovaci- systemy/polohovaci-stoly/s-digitalnim-ukazatelem/dlouh\%C3\%A9-1/pt8625-pae-detail

7. https://www.gme.cz/prumyslovy-koncovy-spinacme-9101-pruzina

8. http://www.unimetra.cz/soubory_zbozi/84_14.pdf

9. http://komaindustry.cz/home/divize-automatickych-parkovacich-systemu/21-parkovaci-dumostrava-fei

10. Hrabovsky L. and Dluhos, D. Calibration of Transducers and of a Coil Compression Spring Constant on the Testing Equipment Simulating the Process of a Pallet Positioning in a Rack Cell. Open Engineering, 9(1), 2019, 631-640.

11. https:/www.hbm.cz/produkty/snimace-sily/c9c/

12. Hrabovsky L., Fedorko G., Kotajny G. and Michalik P. Electromagnetic locking devices of car handling units. Scientific Journal of Silesian University of Technology. Series Transport, 107, 2020. In presss.

13. Hrabovsky L. and Michalik P. A tension equalizer in lift carrying ropes. Advances Science and Technology Research Journal, 11(4), 2017, 326-332. 